\title{
PENGARUH KEPERCAYAAN DAN KEPUASAN TERHADAP LOYALITAS PELANGGAN E- COMMERCE
}

\author{
Eka Satryawati \\ Program Studi/Jurusan Sistem Informasi \\ Univeristas Mohammad Husni Thamrin Jakarta \\ Jl. Raya Pd. Gede No. 23-25, Jakarta, Indonesia \\ emaill ekathufail@gmail.com
}

\begin{abstract}
Abstrak- E-Com, or Electronic Commerce is a rapidly evolving technology in the business world and bythe Internet. The use of E-commerce system, can actually benefit many parties, including the consumer, as well as the producers and sellers (retailers). For example, for the consumer, using the ECommerce can make shopping a short time. In addition, the price of the goods sold via E-commerce is usually cheaper than the prices in the store, because the distribution of producer goods to the seller shorter than conventional stores. Satisfaction, trust and loyalty DBS is the most important factor in business competition. The four variables that will be used in this research is a web interface quality, information quality, security and privacy. This study propose a framework model or combination of models I.Eid Mustafa (2011) and model and Parvez Akbar (2009). The hypothesis is useful to examine the relationship of 4 (four)
\end{abstract}

\section{PENDAHULUAN}

E-Com, atau Electronic Commerce merupakan salah satu teknologi yang berkembang pesat dalam dunia bisnis dan per-internet-an. Penggunaann sistem Ecommerce, sebenarnya dapat menguntungkan banyak pihak, baik pihak konsumen, maupun pihak produsen dan penjual (retailer). Misalnya bagi pihak konsumen, menggunakan E-Commerce dapat membuat waktu berbelanja menjadi singkat. Selain itu, harga barang-barang yang dijual melalui E-Commerce biasanya lebih murah dibandingkan dengan harga di toko, karena jalur distribusi dari produsen barang ke pihak penjual lebih singkat variables affecting trust, satisfaction and loyalty. The method used is distributing questionnaires to 200 customers samples Duta Business School (DBS). Samples used only 200. Structural Equation Model (SEM) was used to analyze the data. The analysis shows that the model does not fit the model of the population but only represent a sample. Based on the proposed model, the web interface Quality and Quality Information positive impact on customer satisfaction. Quality web interface associated with weak consumer confidence, no information related to the quality of customer confidence, Privacy strongly related to customer trust, security is closely linked to customer satisfaction. Customer satisfaction affects customer loyalty, customer satisfaction affects customer trust.

Kata Kunci : influence, trust, satisfaction, loyalty, customer, e-commerce, DBS

\begin{abstract}
Ildibandingkan dengan toko konvensional. Sistem perdagangan dengan cara $E$ Commerce adalah cara yang relatif masih baru di Indonesia,sehingga masih sangat dibutuhkan informasi - informasi tentang transaksi yang aman dan diandalkan dalam hal kepercayaan pelanggan terhadap transaksi E-Commerce,dan juga tingkat efektifitas sehingga melahirkan pelanggan yang memiliki loyalitas terhadap Data Business School. Oleh karena itu judul penelitian ini adalah "Anilsa Loyalitas Pelanggan dalam transaksi E-Commerce (studi kasus : Web Data Business School)"
\end{abstract}

\section{PENELITIAN TERDAHULU}


Mustafa I. Eid (2011) membuat jurnal yang berjudul "Determinants of E-Commerce Customer Satisfaction, Trust, and Loyalty in Saudi Arabia." Seperti yang tampak pada gambar 1 dibawah ini :

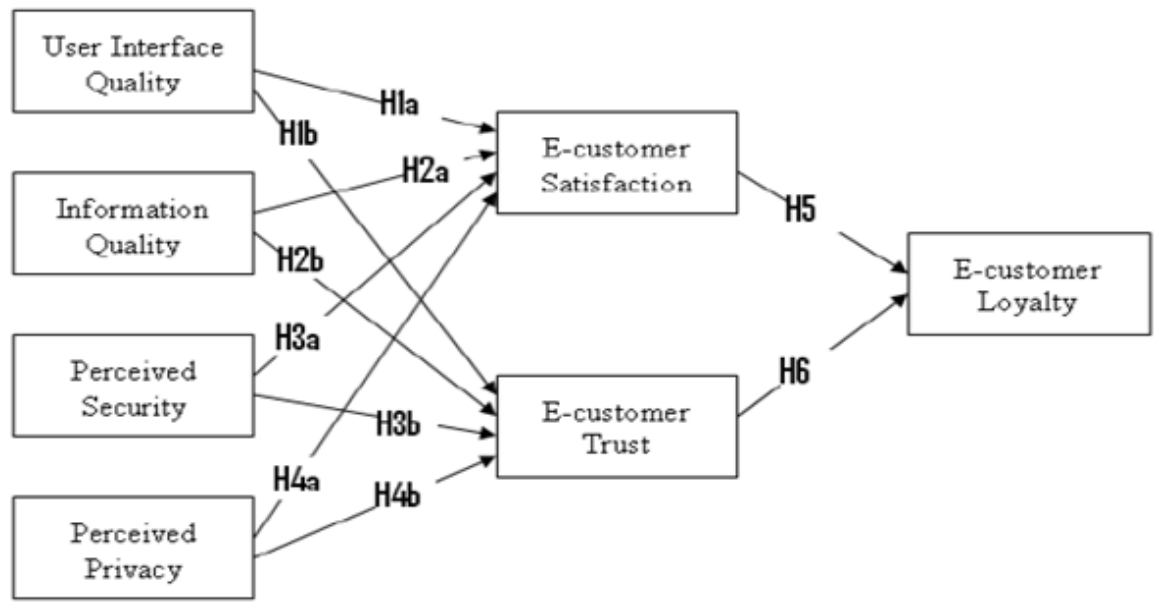

Gambar 1 : Model Penelitian Mustafa I. Eid (2011)

Penelitian yang serupa telah dilakukan oleh peneliti-peneliti terdahulu yang terangkum pada tabel 2.

Tabel 2 : Jurnal Penelitian Terdahulu

\begin{tabular}{|c|c|c|c|c|}
\hline Peneliti & $\begin{array}{c}\text { Obyek } \\
\text { Penelitian }\end{array}$ & Tujuan & $\begin{array}{l}\text { Model dan } \\
\text { Metodologi }\end{array}$ & Hasil Penelitian \\
\hline $\begin{array}{l}\text { Mustafa } \\
\text { I. Eid } \\
(2011)\end{array}$ & $\begin{array}{l}500 \text { kuesioner } \\
\text { dengan populasi } \\
\text { mahasiswa } \\
\text { King Fahd } \\
\text { University of } \\
\text { Petroleum and } \\
\text { Mineral } \\
\text { (KFUPM) dan } \\
\text { karyawan yang } \\
\text { tinggal di timur } \\
\text { Arab Saudi. }\end{array}$ & $\begin{array}{l}\text { Menganalisa } \\
\text { faktor-faktor } \\
\text { yang } \\
\text { mempengaru } \\
\text { hi sejauh } \\
\text { mana } \\
\text { konsumen } \\
\text { Arab Saudi } \\
\text { percaya, } \\
\text { puas, dan } \\
\text { loyal } \\
\text { terhadap } \\
\text { B2C e- } \\
\text { commerce. }\end{array}$ & $\begin{array}{l}\text { Model : TAM } \\
\text { (Technology } \\
\text { Acceptance } \\
\text { Model) yang } \\
\text { dikembangkan } \\
\text { dari model } \\
\text { TRA (The } \\
\text { Theory of } \\
\text { Reasoned } \\
\text { Action). } \\
\text { Metodologi : } \\
\text { Menyebarkan } \\
\text { kuesioner } \\
\text { dengan bahasa } \\
\text { Inggris dan } \\
\text { bahasa Arab } \\
\text { dan pengujian } \\
\text { hipotesis } \\
\text { menggunakan } \\
\text { teknik SEM. }\end{array}$ & $\begin{array}{l}\text { - Antarmuka website } \\
\text { dan kualitas informasi } \\
\text { berdampak positif } \\
\text { terhadap kepuasan } \\
\text { konsumen. } \\
\text { - } \text { Antarmuka yang } \\
\text { berkualitas sangat } \\
\text { berkaitan dengan } \\
\text { kepercayaan } \\
\text { pelanggan. } \\
\text { Kualitas informasi } \\
\text { tidak berkaitan } \\
\text { dengan kepercayaan } \\
\text { pelanggan. } \\
\text { Keamanan dan } \\
\text { privasi sangat terkait } \\
\text { dengan kepercayaan } \\
\text { pelanggan. } \\
\text { Keamanan dan } \\
\text { privasi berkaitan } \\
\text { lemah dengan } \\
\text { kepuasan pelanggan. }\end{array}$ \\
\hline $\begin{array}{l}\text { Gefen et } \\
\text { al }\end{array}$ & $\begin{array}{l}\text { mahasiswa } \\
\text { tingkat sarjana } \\
\text { dan } \\
\text { pascasarjana } \\
\text { dari } \\
\text { universitas } \\
\text { bisnis } \\
\text { terkemuka } \\
\text { Amerika yang }\end{array}$ & $\begin{array}{l}\text { Meneliti } \\
\text { pengaruh } \\
\text { kualitas } \\
\text { pelayanan, } \\
\text { kepercayaan } \\
\text { konsumen } \\
\text { terhadap } \\
\text { loyalitas } \\
\text { konsumen }\end{array}$ & $\begin{array}{l}\text { Alat analisis } \\
\text { yang } \\
\text { digunakan } \\
\text { adalah } \\
\text { Principal } \\
\text { Components } \\
\text { Factor (PCA) } \\
\text { Analysis dan } \\
\text { partial least }\end{array}$ & 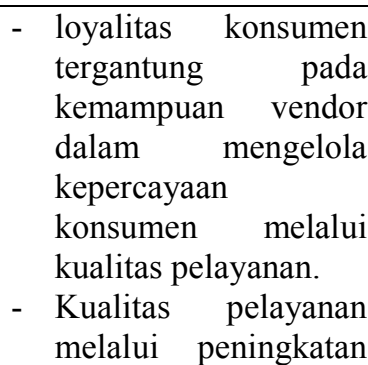 \\
\hline
\end{tabular}




\begin{tabular}{|c|c|c|c|c|}
\hline & $\begin{array}{l}\text { melakukan } \\
\text { transaksi } \\
\text { pembelian } \\
\text { buku di situs } \\
\text { amazon.com. } \\
\text { kuesioner } \\
\text { secara benar } \\
\text { dan lengkap } \\
\text { sebanyak } 160 \\
\text { responden. }\end{array}$ & $\begin{array}{l}\text { pada } \\
\text { mahasiwa di } \\
\text { Amerika }\end{array}$ & $\begin{array}{l}\text { squares (PLS). } \\
\text { Instrumen } \\
\text { pengumpulan } \\
\text { data } \\
\text { menggunakan } \\
\text { kuesioner } \\
\text { dengan tujuh } \\
\text { skala likert }\end{array}$ & $\begin{array}{l}\text { kepercayaan } \\
\text { mempunyai } \\
\text { kontribusi yang besar } \\
\text { di dalam membentuk } \\
\text { loyalitas konsumen }\end{array}$ \\
\hline $\begin{array}{l}\text { Hsiu } \\
\text { Yuan Hu } \\
\text { et al. } \\
(2011)\end{array}$ & $\begin{array}{l}1100 \text { pasien di } \\
15 \text { rumah sakit } \\
\text { di Taiwan. }\end{array}$ & $\begin{array}{l}\text { Menganalisa } \\
\text { hubungan } \\
\text { antara tiga } \\
\text { atribut } \\
\text { kepuasan } \\
\text { pelanggan, } \\
\text { keluhan } \\
\text { pelanggan, } \\
\text { dan loyalitas } \\
\text { pelanggan } \\
\text { pada } \\
\text { pelayanan } \\
\text { kesehatan di } \\
\text { Taiwan. }\end{array}$ & $\begin{array}{l}\text { Model : model } \\
\text { terintegrasi } \\
\text { Kano dan } \\
\text { model indeks } \\
\text { kepuasan } \\
\text { pelanggan } \\
\text { Metodologi : } \\
\text { Menyebarkan } \\
\text { kuesioner } \\
\text { dengan } \\
\text { pengujian } \\
\text { hipotesis } \\
\text { menggunakan } \\
\text { teknik SEM. }\end{array}$ & $\begin{array}{l}\text { - Atribut dimensi satu } \\
\text { dan atribut menarik } \\
\text { berpengaruh positif } \\
\text { terhadap kepuasan } \\
\text { pelanggan. } \\
\text { - } \text { Atribut wajib tidak } \\
\text { berpengaruh langsung } \\
\text { terhadap kepuasan } \\
\text { pelanggan. } \\
\text { - Kepuasan pelanggan } \\
\text { berpengaruh negatif } \\
\text { dengan keluhan } \\
\text { pelanggan. } \\
\text { - Keluhan pelanggan } \\
\text { tidak berpengaruh } \\
\text { langsung terhadap } \\
\text { loyalitas pelanggan. }\end{array}$ \\
\hline $\begin{array}{l}\text { Intan } \\
\text { Salwani } \\
\text { Mohame } \\
\text { d dan } \\
\text { Norzaidi } \\
\text { Mohd } \\
\text { Daud } \\
\text { (2006 }\end{array}$ & $\begin{array}{l}\text { Peneltian } \\
\text { bersifat } \\
\text { kualitatif }\end{array}$ & $\begin{array}{l}\text { Penelitian } \\
\text { ini menguji } \\
\text { dampak e- } \\
\text { commerce } \\
\text { penggunaan } \\
\text { pada kinerja } \\
\text { usaha di } \\
\text { sektor } \\
\text { pariwisata } \\
\text { Malaysia }\end{array}$ & $\begin{array}{l}\text { Model E- } \\
\text { Value. Model } \\
\text { yang } \\
\text { menggunakan } \\
\text { faktor } \\
\text { teknologi,orga } \\
\text { nisasi dan } \\
\text { lingkungan } \\
\text { sebagai faktor } \\
\text { penggerak e } \\
\text { commerce } \\
\text { Dengan } \\
\text { tambahan } \\
\text { variabel } \\
\text { moderating } \\
\text { dan mediator }\end{array}$ & 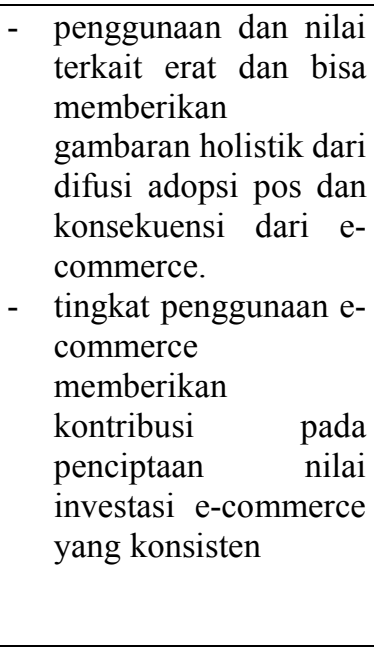 \\
\hline $\begin{array}{l}\text { Akbar } \\
\text { dan } \\
\text { Parvez } \\
(2009)\end{array}$ & $\begin{array}{l}304 \text { pelanggan } \\
\text { dari perusahaan } \\
\text { telekomunikasi } \\
\text { swasta di } \\
\text { Bangladesh. }\end{array}$ & $\begin{array}{l}\text { Menganalisa } \\
\text { keterkaitan } \\
\text { pelanggan } \\
\text { terhadap } \\
\text { kualitas } \\
\text { layanan, } \\
\text { kepercayaan } \\
\text { dan } \\
\text { kepuasan } \\
\text { pelanggan. }\end{array}$ & $\begin{array}{l}\text { Model : dua } \\
\text { tingkatan } \\
\text { analisa. } \\
\text { Metodologi : } \\
\text { Menyebarkan } \\
\text { kuesioner } \\
\text { terstruktur dan } \\
\text { pengujian } \\
\text { hipotesis } \\
\text { menggunakan } \\
\text { analisis faktor } \\
\text { konfirmatori } \\
\text { dan }\end{array}$ & $\begin{array}{l}\text { Kehandalan, data } \\
\text { tanggap, jaminan, } \\
\text { empati, dan tampilan } \\
\text { fisik secara } \\
\text { signifikan } \\
\text { berpengaruh } \\
\text { terhadap kepuasan } \\
\text { dan loyalitas } \\
\text { pelanggan. } \\
\text { Kepercayaan secara } \\
\text { signifikan } \\
\text { berpengaruh } \\
\text { terhadap loyalitas }\end{array}$ \\
\hline
\end{tabular}




\begin{tabular}{|c|c|c|c|c|}
\hline & & & $\begin{array}{l}\text { pemodelan } \\
\text { persamaan } \\
\text { struktural. }\end{array}$ & $\begin{array}{l}\text { pelanggan. } \\
\text { Kepuasan pelanggan } \\
\text { dan loyalitas } \\
\text { pelanggan secara } \\
\text { positif dan signifikan } \\
\text { berkorelasi. }\end{array}$ \\
\hline $\begin{array}{l}\text { Ari } \\
\text { Wijayanti } \\
(2008)\end{array}$ & $\begin{array}{l}135 \text { pelanggan } \\
\text { yang memakai } \\
\text { produk kartu } \\
\text { seluler praBayar } \\
\text { Mentari-Indosat } \\
\text { wilayah } \\
\text { Semarang } \\
\text { selama } 1 \text { tahun } \\
\text { atau lebih. }\end{array}$ & $\begin{array}{l}\text { Menguji } \\
\text { faktor-faktor } \\
\text { yang } \\
\text { mempengaru } \\
\text { hi loyalitas } \\
\text { pelanggan. }\end{array}$ & $\begin{array}{l}\text { Metodologi : } \\
\text { wawancara } \\
\text { dan } \\
\text { menyebarkan } \\
\text { kuesioner dan } \\
\text { pengujian } \\
\text { hipotesis } \\
\text { menggunakan } \\
\text { SEM. }\end{array}$ & $\begin{array}{ll}\text { - } & \text { Kualitas pelayanan } \\
\text { memiliki dampak } \\
\text { positif pada kepuasan } \\
\text { pelanggan. } \\
\text { Kualitas produk } \\
\text { memiliki dampak } \\
\text { positif pada kepuasan } \\
\text { pelanggan. } \\
\text { Harga produk } \\
\text { memiliki dampak } \\
\text { positif pada kepuasan } \\
\text { pelanggan. } \\
\text { Kepuasan pelanggan } \\
\text { memiliki dampak } \\
\text { positif pada biaya } \\
\text { yang dikeluarkan. } \\
\text { Biaya yang } \\
\text { dikeluarkan memiliki } \\
\text { dampak positif } \\
\text { terhadap loyalitas } \\
\text { pelanggan. }\end{array}$ \\
\hline
\end{tabular}

\section{METODE PENELITIAN}

Metode yang digunakan dalam penelitian ini adalah gabungan dari model penelitian Mustafa I

Eid (2011) dan model penelitian Akbar dan Parvez (2009) yang terlihat pada gambar 2.

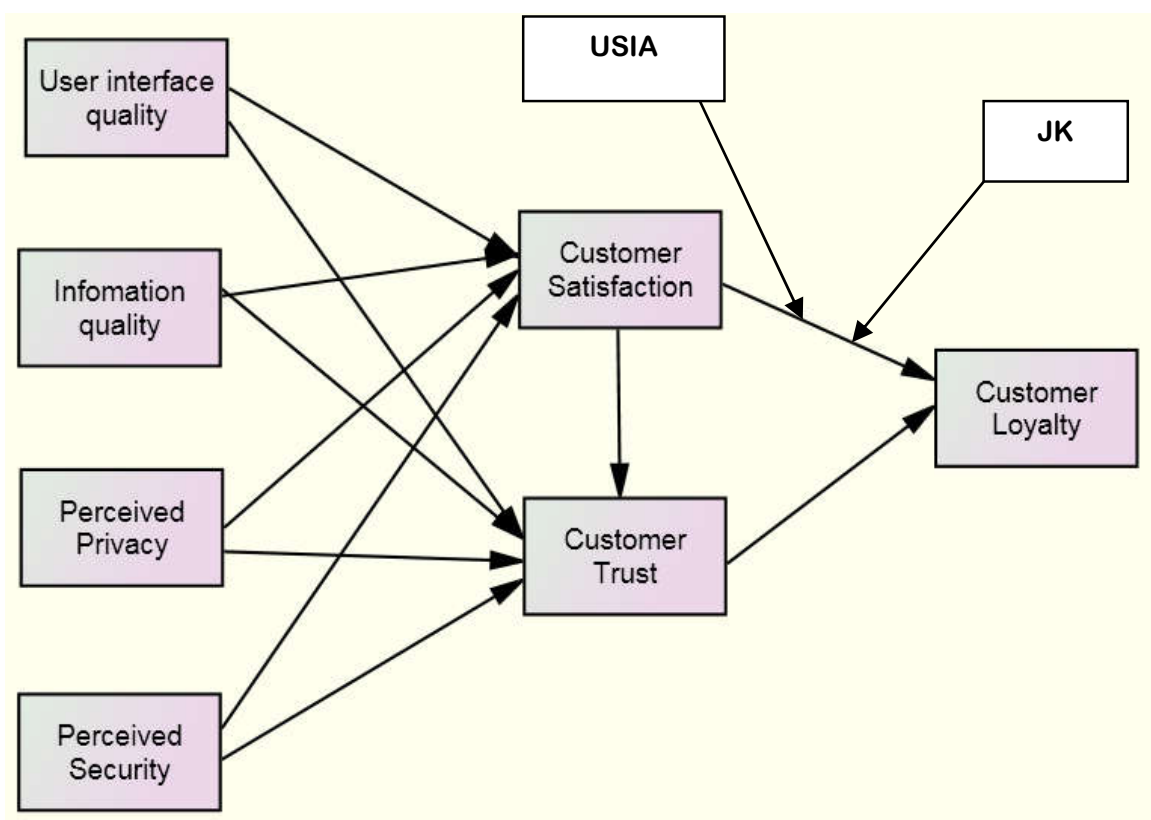

Gambar 2 : Kerangka Konsep Pemikiran 
Menurut Hair et.al (1995) dalam Andi Listyarso (2005) yang menyatakan bahwa ukuran sampel yang representatif mewakili responden dalam analisis SEM adalah sebanyak 100 sampai 200 sampel. Peneliti menyebarkan 200 kuesioner kepada seluruh pelanggan Warnet Sarang bangsawan. Sampel disebarkan di Warnet Sarang Bangsawan karena alasan lokasi warnet yang strategis berada di pinggir jalan besar yang ramai dilalui kendaraan dan jumlah komputer yang cukup banyak. Instrumen penelitian yang tertuang pada kuesioner dapat dilihat pada tabel 3 .
Teknik yang digunakan dalam penarikan sampel adalah purposive sampling yaitu teknik penarikan sampel yang dilakukan berdasarkan karakteristik yang ditetapkan terhadap elemen populasi target yang disesuaikan dengan tujuan atau masalah penelitian. Sampel akan dikelompokkan sesuai usia dan jenis kelamin pelanggan. Usia dikelompokkan menjadi <2 5 tahun dan $\geq 25$ tahunn, sedangka jenis kelamin pelanggan dikelompokkan menjadi laki - laki dan perempuan. Penyebaran Kuesioner dilakukan pada bulan Juni - Agustus 2012. Pengumpulan data dilakukan pada bulan Agustus 2012

Tabel 3 : Kisi-Kisi Penelitian

\begin{tabular}{|c|c|c|}
\hline No. & Variabel & Indikator \\
\hline 1. & $\begin{array}{l}\text { Antarmuka Website } \\
\text { (Mustafa I Eid, 2011) }\end{array}$ & $\begin{array}{ll}- & \text { Mudah digunakan } \\
\text { - } & \text { Visual Menarik } \\
\text { - } & \text { Meningkatkan efektifitas pencarian }\end{array}$ \\
\hline 2. & $\begin{array}{l}\text { Kualitas Informasi } \\
\text { (Mustafa I Eid, 2011) }\end{array}$ & $\begin{array}{ll}\text { - } & \text { Menyediakan informasi produk/jasa yang } \\
& \text { relevan } \\
\text { - } & \text { Memfasilitasi cara membeli atau menjual } \\
& \text { produk } \\
\text { - } & \text { Mudah dalam transaksi pembelian }\end{array}$ \\
\hline 3. & $\begin{array}{l}\text { Keamanan } \\
\text { (Mustafa I Eid, 2011) }\end{array}$ & $\begin{array}{ll}\text { - } & \text { Memiliki mekanisme untuk memastikan } \\
\text { transmisi yang aman dari informasi pengguna } \\
\text { - } & \text { Data aman dari hacker } \\
\text { - } & \text { Tidak ada resiko keuangan }\end{array}$ \\
\hline 4. & $\begin{array}{l}\text { Privasi } \\
\text { (Mustafa I Eid, 2011) }\end{array}$ & $\begin{array}{ll}\text { - } & \text { Perlindungan data pribadi } \\
\text { - } & \text { Data pribadi hanya untuk aktifasi } \\
\text { - } & \text { Aman dalam pengiriman data }\end{array}$ \\
\hline 5. & $\begin{array}{l}\text { Kepercayaan Pelanggan } \\
\text { (Mustafa I Eid, 2011) }\end{array}$ & $\begin{array}{ll}\text { - } & \text { Dapat dipercaya dan jujur } \\
\text { - } & \text { Menanamkan kepercayaan } \\
\text { - } & \text { Memenuhi janji }\end{array}$ \\
\hline 6. & $\begin{array}{l}\text { Kepuasan pelanggan } \\
\text { (Akbar dan Parvez, } \\
\text { 2009) dan (Mustafa I } \\
\text { Eid, 2011) }\end{array}$ & $\begin{array}{l}\text { - Kemampuan perusahaanmemenuhi harapan } \\
\text { konsumen setelah membeli produk, } \\
\text { - Kemampuan perusahaan memberikan kepuasan } \\
\text { yang tinggi kepada konsumen melalui upaya } \\
\text { perbaikan di sektor kualitas pelayanan atau } \\
\text { produk, } \\
\text { - Kemampuan perusahaan memenuhi harapan } \\
\text { yang ada di benak konsumen sebelum } \\
\text { konsumen melakukan pembelian produk. }\end{array}$ \\
\hline 7. & $\begin{array}{l}\text { Loyalitas pelanggan } \\
\text { (Akbar dan Parvez, }\end{array}$ & $\begin{array}{ll}- & \text { Niat untuk membeli kembali, } \\
\text { - } & \text { Merekomendasikan perusahaan kepada orang }\end{array}$ \\
\hline
\end{tabular}




\begin{tabular}{|l|l|l|}
\hline 2009) dan (Mustafa I & lain, \\
Eid, 2011) & $-\quad$ Komitmen terhadap perusahaan. \\
\hline
\end{tabular}

4.

Profil pelanggan Duta Business School dapat dilihat pada profil responden yang terdapat pada tabel

Tabel 4 : Profil Responden

\begin{tabular}{|c|c|c|}
\hline Klasifikasi & Jumlah & Persentase (\%) \\
\hline \multicolumn{3}{|c|}{ Jenis Kelamin } \\
\hline Laki-Laki & 89 & 44.5 \\
\hline Perempuan & 111 & 55.5 \\
\hline Jumlah & 200 & 100 \\
\hline \multicolumn{3}{|c|}{ Usia } \\
\hline$<25$ tahun & 118 & 59 \\
\hline$\geq 25$ tahun & 82 & 41 \\
\hline Jumlah & 200 & 100 \\
\hline \multicolumn{3}{|c|}{ Pekerjaan } \\
\hline Mahasiswa & 100 & 50 \\
\hline Karyawan & 73 & 36,5 \\
\hline Ibu RT & 20 & 10 \\
\hline Pengusaha & 7 & 3,5 \\
\hline Jumlah & 200 & 100 \\
\hline \multicolumn{3}{|c|}{ Pendidikan Terakhir } \\
\hline SMP & 15 & 7,5 \\
\hline SMA & 53 & 26,5 \\
\hline S1 & 128 & 64 \\
\hline S2 & 4 & 2 \\
\hline Jumlah & 200 & 100 \\
\hline
\end{tabular}

Sumber : Data primer yang sudah diolah (2012)

4. Hasil dan Analisa dengan SEM

Path diagram ini melibatkan 4 variabel eksogen dengan 12 indikator dan 3 variabel endogen dengan 9 indikator. Variabel eksogen terdiri dari Kualitas Antarmuka Web (UQ), Kualitas Informasi (IQ), dan Keamanan (PS), dan Privasi (PP) sedangkan variabel endogen terdiri dari Kepercayaan Pelanggan (CT), Kepuasaan Pelanggan (CS) dan Loyalitas Pelanggan (CL). Hubungan kausal antara variabel eksogen dan endogen dapat dilihat pada gambar 3 berikut ini. 


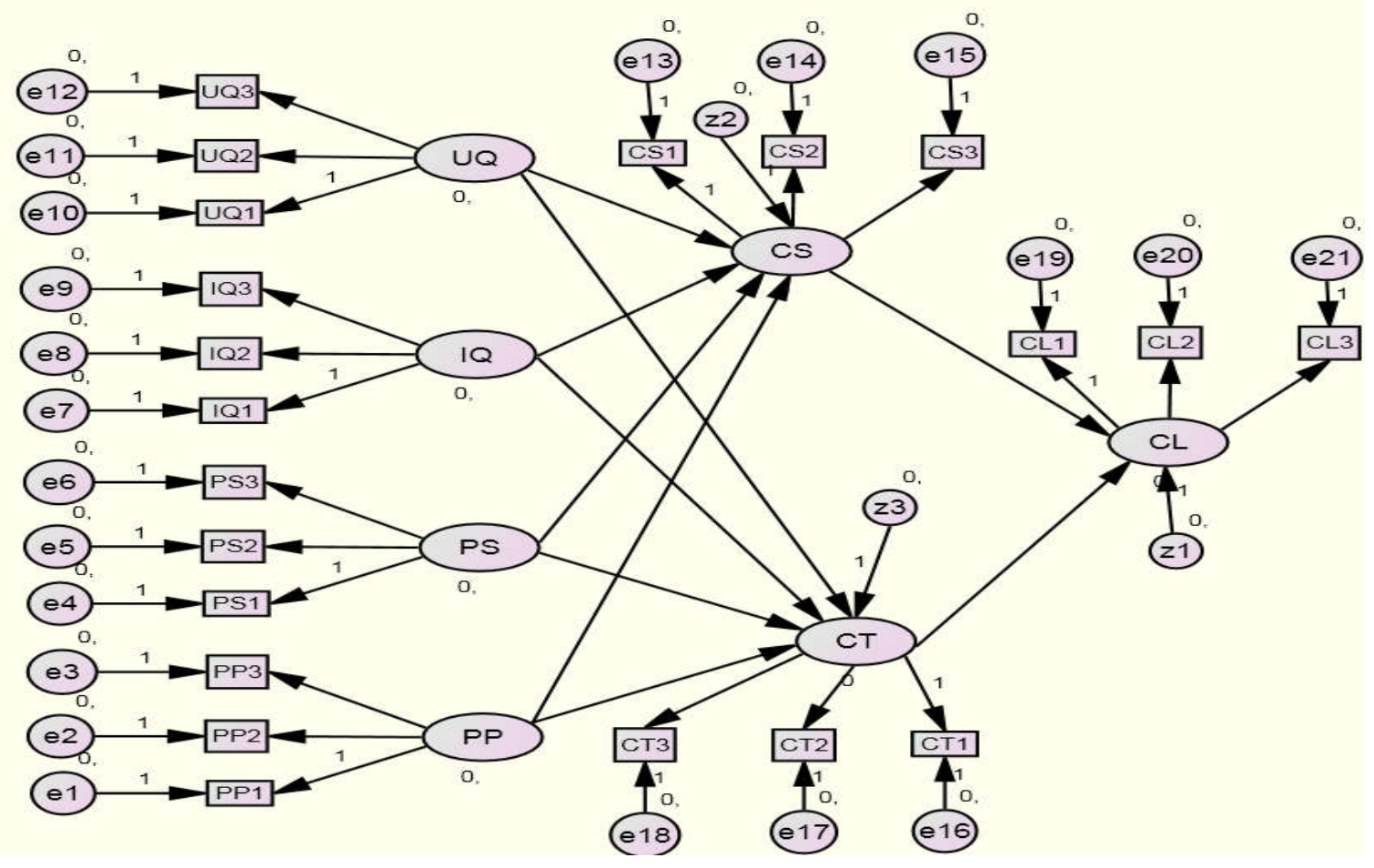

Gambar 3 : Path Diagram

Pada uji kesesuaian diajukan hipotesis sebagai berikut :

$\mathrm{H}_{0} \quad$ : Model yang diajukan pada penelitian tidak merepresentasikan karakteristik atau perilaku dari populasi melainkan hanya merepresentasikan sampel yang ditunjukkan dengan nilai probability $(\mathrm{p}$ $<0,05)$.

$\mathrm{H}_{1} \quad$ : $\quad$ Model yang diajukan pada penelitian merepresentasikan karakteristik atau perilaku dari populasi yang ditunjukkan dengan nilai probability $(\mathrm{p}$ $\geq 0,05$ ).

Hasil yang terlihat pada gambar 4.2 menunjukkan bahwa probability $(p)=0,000$. Hasil tersebut menunjukkan bahwa $\mathrm{H}_{1}$ ditolak, yang berarti model yang diajukan pada penelitian tidak merepresentasikan karakteristik atau perilaku dari populasi melainkan hanya merepresentasikan sampel atau disebut juga model tidak fit, karena nilai probability $<0,05$.

Hasil Uji Signifikansi terlihat pada gambar 4.

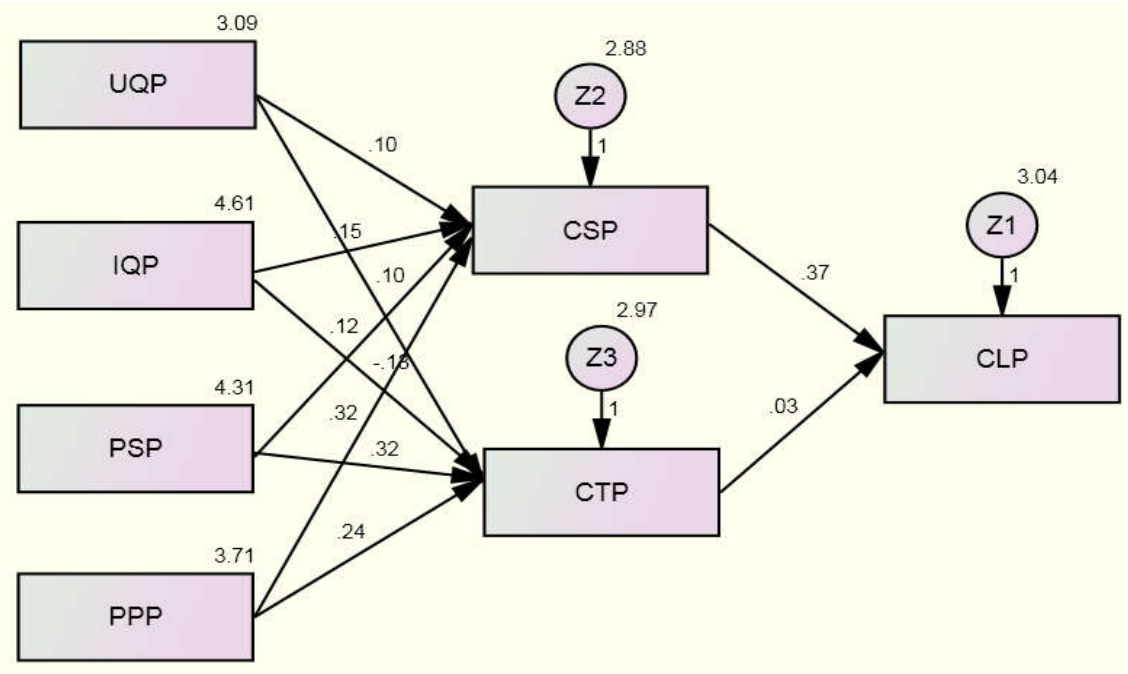


Gambar 4 : Hasil Uji Signifikansi

Pada tabel 4 akan ditampilkan koefisien regresi dan nilai $p$ masing-masing variabel.

Tabel 4 :

Koefisien Regresi dan

Nilai Probabilitas Model Jalur Awal

\begin{tabular}{|ccc|cc|}
\hline \multicolumn{3}{|c|}{ Hubungan Kausal } & Koefisien Regresi & P \\
\hline CSP & $<---$ & UQP & $\mathbf{. 1 0 2}$ & $\mathbf{. 1 3 6}$ \\
CTP & $<---$ & UQP & $\mathbf{. 1 0 0}$ &. $\mathbf{1 5 1}$ \\
CSP & $<---$ & IQP & .155 & .006 \\
CTP & $<---$ & IQP & $\mathbf{- . 1 3 0}$ & $\mathbf{. 0 2 2}$ \\
CSP & $<---$ & PSP & .123 & .033 \\
CTP & $<---$ & PSP & .321 & $* * *$ \\
CSP & $<---$ & PPP & .324 & $* * *$ \\
CTP & $<---$ & PPP & .239 & $* * *$ \\
CLP & $<---$ & CSP & .367 & $* * *$ \\
CLP & $<---$ & CTP & $\mathbf{. 0 3 2}$ &. $\mathbf{6 1 7}$ \\
\hline
\end{tabular}

Huruf yang dicetak tebal pada tabel 4 dianggap tidak signifikan dan akan dikeluarkan dari model. Hubungan antara UQP (User Interface Quality) dengan CSP (Customer Satisfaction), UQP dengan CTP, CTP dengan CLP dianggap tidak signifikan karena $p>0,05$ dan Sedangkan hubungan antara IQP dengan CTP tidak signifikan karena nilai Koefisien Regresinya negatif. Hubungan yang dianggap signifikan adalah hubungan antara IQP dengan CSP, PSP dengan CSP, PSP dengan CTP , PPP dengan CSP, PPP dengan CTP dan CSP dengan CLP. Seluruh tahapan pengujian telah dilakukan dan mendapatkan hasil dari hipotesis umum yaitu tidak semua variabel berpengaruh secara signifikan terhadap kepercayaan,kepuasan dan loyalitas pelanggan. Hasil hipotesis khusus dapat dilihat pada tabel 4.5 berdasarkan :

Seluruh tahapan pengujian telah dilakukan dan mendapatkan hasil dari hipotesis umum yaitu tidak semua variabel berpengaruh secara signifikan terhadap kepuasan dan loyalitas pelanggan. Hasil hipotesis khusus dapat dilihat pada tabel 5 berdasarkan :

$\mathrm{H}_{1}$ : Diterima apabila nilai $\mathrm{p}<0,05$.

$\mathrm{H}_{1}$ : Ditolak apabila nilai $\mathrm{p} \geq 0,05$.

Tabel 5 : Hasil Hipotesis Khusus

\begin{tabular}{|c|c|c|}
\hline Hipotesis & Deskripsi & Hasil \\
\hline UQa & $\begin{array}{l}\text { Kualitas antarmuka web berpengaruh } \\
\text { secara signifikan terhadap Kepuasan } \\
\text { Pelanggan }\end{array}$ & HO ditolak \\
\hline
\end{tabular}




\begin{tabular}{|c|c|c|}
\hline UQb & $\begin{array}{c}\text { Kualitas antarmuka web berpengaruh } \\
\text { secara signifikan terhadap } \\
\text { Kepercayaan Pelanggan }\end{array}$ & HO ditolak \\
\hline IQa & $\begin{array}{c}\text { Kualitas Informasi berpengaruh secara } \\
\text { signifikan tehadap Kepuasan } \\
\text { Pelanggan }\end{array}$ & HO diterima \\
\hline$I Q b$ & $\begin{array}{c}\text { Kualitas Informasi berpengaruh secara } \\
\text { signifikan terhadap Kepercayaan } \\
\text { Pelanggan }\end{array}$ & HO ditolak \\
\hline $\mathrm{PPa}$ & $\begin{array}{l}\text { Privasi berpengaruh secara signifikan } \\
\text { terhadap Kepuasan Pelanggan }\end{array}$ & HO diterima \\
\hline $\mathrm{PPb}$ & $\begin{array}{l}\text { Privasi berpengaruh secara siginifikan } \\
\text { terhadap Kepercayaan Pelanggan }\end{array}$ & HO diterima \\
\hline PSa & $\begin{array}{c}\text { Keamanan berpengaruh secara } \\
\text { signifikan terhadap Kepuasan } \\
\text { Pelanggan }\end{array}$ & HO diterima \\
\hline PSb & $\begin{array}{l}\text { Keamanan berpengaruh secara } \\
\text { signifikan terhadap Kepercayan } \\
\text { Pelanggan }\end{array}$ & HO diterima \\
\hline $\mathrm{CSb}$ & $\begin{array}{c}\text { Kepuasan Pelanggan berpengaruh } \\
\text { secara signifikan terhadap Loyalitas } \\
\text { Pelanggan }\end{array}$ & HO diterima \\
\hline CT & $\begin{array}{c}\text { Kepercayaan Pelanggan berpengaruh } \\
\text { secara signifikan terhadap Loyalitas } \\
\text { Pelanggan }\end{array}$ & HO ditolak \\
\hline
\end{tabular}

Kepercayaan pelanggan dipengaruhi secara signifikan oleh keamanan dan Privasi. Variabel yang tidak berpengaruh secara signifikan terhadap Kepercayaan Pelanggan adalah Kualitas antarmuka web dan kualitas informasi. Kepuasan Pelanggan dipengaruhi secara signifikan oleh kualitas informasi, privasi dan Keamanan. Loyalitas pelanggan hanya dipengaruhi secara signifikan oleh Kepuasan pelanggan, Kualitas Informasi, Privasi dan Keamanan. Variabel yang tidak berpengaruh secara signifikan terhadap loyalitas pelanggan dan kepuasan pelanggan adalah Kualitas antarmuka web.

Uji Signifikansi telah dilakukan dengan menghapus beberapa path atau variabel yang tidak signifikan. Hasil yang diperoleh dapat dilihat pada model akhir (gambar 5) dan hasil lengkap pada model akhir ini dapat dilihat pada tabel 6 . 


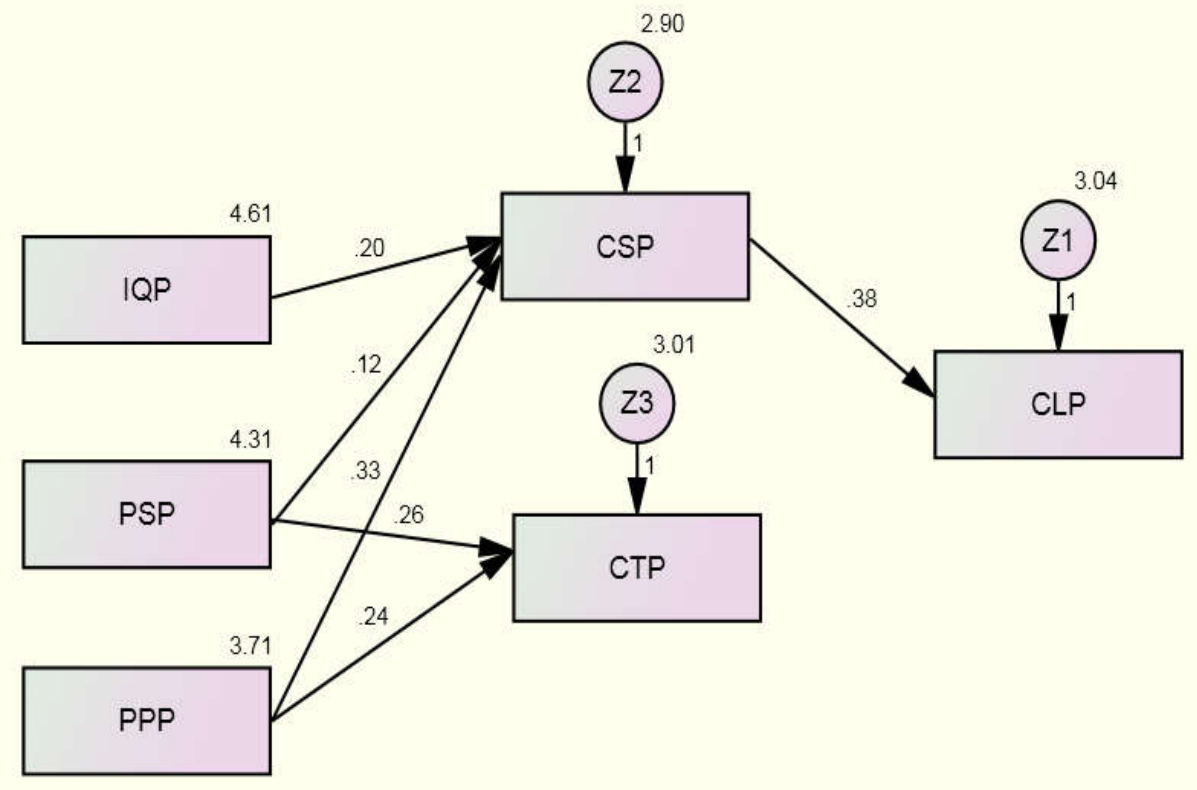

Gambar 5 : Model Jalur Akhir 1 dengan Koefisien Regresi

Karena CTP tidak mempengaruhi CLP dan tidak terhubung ke CLP, sehingga CTP dihapus. Hasil akhir dari model penelitian ini adalah :

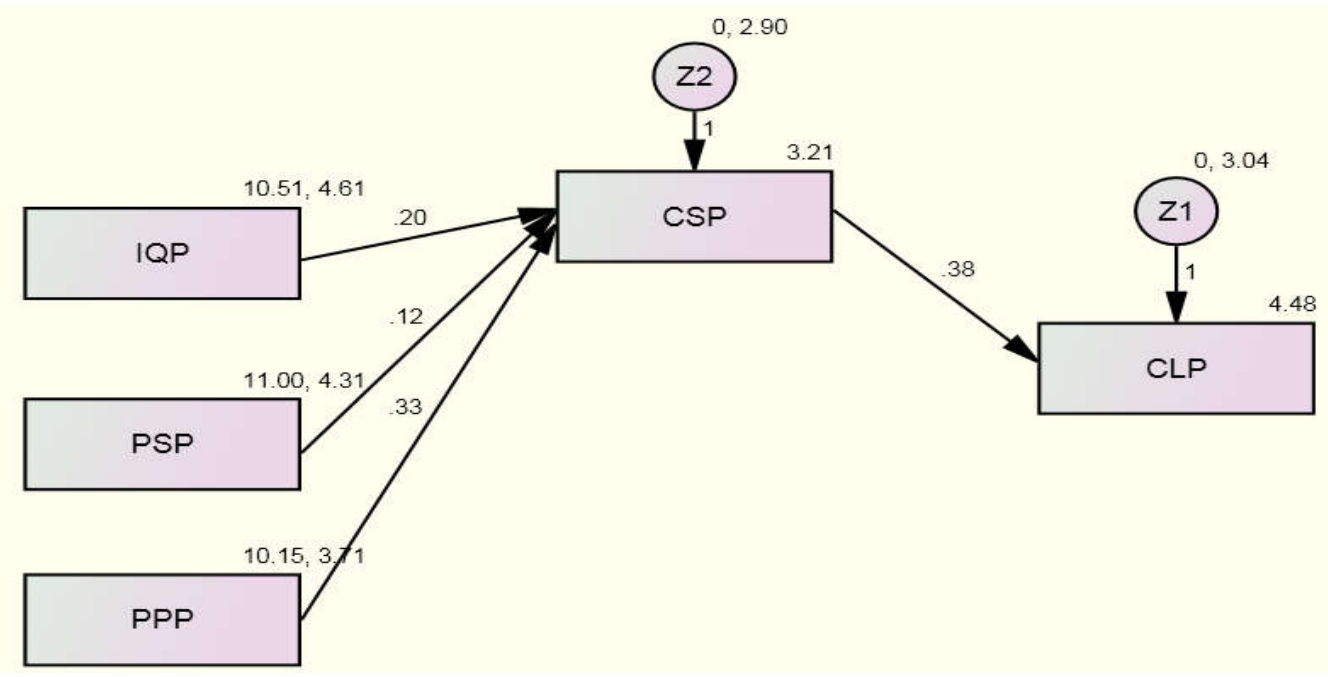

Gambar 6. Model Jalur Akhir 2 dan Koefisien Regresi

Tabel 6. Koefisien Regresi Jalur Akhir 2

\begin{tabular}{|l|c|c|c|}
\hline Hubungan Kausal & Deskripsi & $\begin{array}{c}\text { Koefisien } \\
\text { Regresi }\end{array}$ & $P$ \\
\hline CSP <--- IQP & $\begin{array}{c}\text { Kualitas Informasi } \\
\text { berpengaruh secara signifikan } \\
\text { tehadap Kepuasan Pelanggan }\end{array}$ & .204 & $* * *$ \\
\hline
\end{tabular}




\begin{tabular}{|ccc|c|c|c|}
\hline CSP & $<---$ & PPP & $\begin{array}{c}\text { Privasi berpengaruh secara } \\
\text { signifikan tehadap Kepuasan } \\
\text { Pelanggan }\end{array}$ & .333 & $* * *$ \\
\hline $\mathrm{CSP}$ & $<---$ & $\mathrm{PSP}$ & $\begin{array}{c}\text { Keamanan berpengaruh } \\
\text { secara signifikan tehadap } \\
\text { Kepuasan Pelanggan }\end{array}$ & .123 & 0.35 \\
\hline $\mathrm{CLP}$ & $<---$ & $\mathrm{CSP}$ & $\begin{array}{c}\text { Kepuasan Pelanggan } \\
\text { berpengaruh secara signifikan } \\
\text { terhadap Loyalitas Pelanggan }\end{array}$ & .383 & $* * *$ \\
\hline
\end{tabular}

Persamaan berdasarkan koefisien regresi dan nilai Intercept dapat dituliskan sebagai berikut : - CSP $=3.214+0.204 \mathrm{IQP}+0.123 \mathrm{PSP}+0.333 \mathrm{PPP}$

$-\mathrm{CLP}=4.481+0.383 \mathrm{CSP}$

Hasil Uji Keragaman dengan Variabel Moderasi sebagai berikut :

1. Usia

$\mathrm{H}_{0} \quad$ :

Tidak ada perbedaan usia pelanggan yang mempengaruhi

secara signifikan kepuasan pelanggan terhadap loyalitas pelanggan Duta Business School (DBS).

Berdasarkan hasil output variabel usia pada model fit summary bagian Structural Weight terlihat bahwa nilai probability yaitu 0 yang berarti bahwa nilai $p<0.05$. Hal ini menunjukkan bahwa $\mathrm{HO}$ ditolak yang berarti
$\mathrm{H}_{1} \quad$ : $\quad$ Tidak ada perbedaan usia pelanggan yang mempengaruhi secara signifikan kepuasan pelanggan terhadap loyalitas pelanggan Duta Business School (DBS).

a) Kriteria $<25$ Tahun.

Hipotesis khusus yang diajukan pada penelitian ini untuk kriteria $<25$ tahun adalah sebagai berikut :

$\mathrm{H}_{0} \quad: \quad \begin{aligned} & \text { Tidak ada pengaruh secara } \\ & \text { signifikan kepuasan pelanggan } \\ & \text { terhadap loyalitas pelanggan } \\ & \text { oleh pelanggan yang usianya } \\ & \end{aligned}$
25 tahun.
$\mathrm{H}_{1} \quad: \quad \begin{aligned} & \text { Ada pengaruh secara signifikan } \\ & \text { kepuasan pelanggan terhadap } \\ & \text { loyalitas pelanggan oleh } \\ & \text { pelanggan yang usianya } \\ & \text { tahun. }\end{aligned}$

ada perbedaan usia pelanggan yang mempengaruhi secara signifikan kepuasan pelanggan terhadap loyalitas pelanggan Duta Business School (DBS).

Berdasarkan hasil output regression weight dengan kriterian usia $<25$ tahun terlihat bahwa hubungan antara variabel CSP
(Kepuasan Pelanggan) dengan variabel CLP (Loyalitas Pelanggan) memiliki nilai $P={ }^{* * *}$. Ini berarti $\mathrm{H}_{0}$ ditolak, karena nilai dibawah batas 
minimum yaitu 0,05 . Oleh karena itu dapat disimpulkan bahwa kepuasan pelanggan mempengaruhi secara signifikan loyalitas pelanggan oleh pelanggan yang mempunyai usia $<25$ tahun.

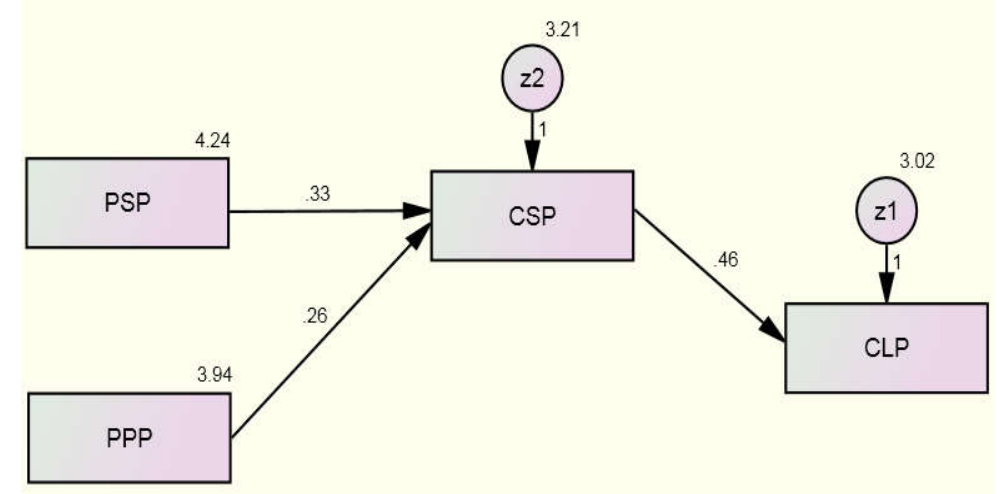

Gambar 7. Model Moderasi $<25$

b) Kriteria $\geq 25$ tahun

Hipotesis khusus yang diajukan pada penelitian ini untuk kriteria $\geq 25$ tahun adalah sebagai berikut :

$\begin{array}{lll}\mathrm{H}_{0} \quad: \quad \begin{array}{l}\text { Tidak ada pengaruh secara } \\ \text { signifikan kepuasan pelanggan } \\ \text { terhadap loyalitas pelanggan } \\ \text { oleh pelanggan yang usianya }\end{array} & \mathrm{H}_{1} \quad: \quad \begin{array}{l}\text { Ada pengaruh secara signifikan } \\ \text { kepuasan pelanggan terhadap }\end{array} \\ >=25 \text { tahun. } & \begin{array}{l}\text { loyalitas pelanggan oleh } \\ \text { pelanggan yang usianya }>=25 \\ \text { tahun. }\end{array}\end{array}$

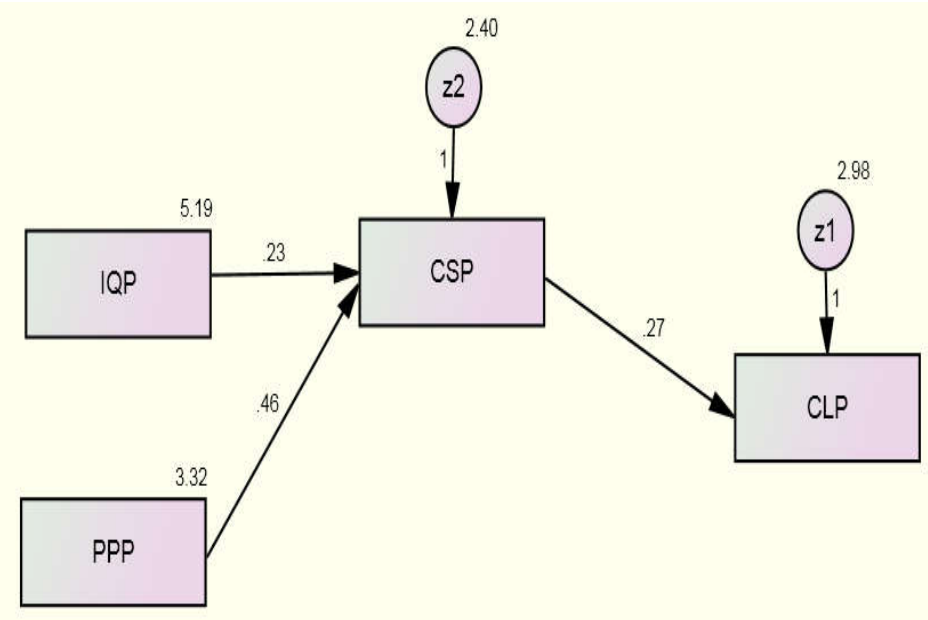


Berdasarkan hasil output regression weight dengan kriterian usia $>=25$ tahun terlihat bahwa hubungan antara variabel CSP (Kepuasan Pelanggan) dengan variabel CLP (Loyalitas Pelanggan) memiliki nilai $P=0.010$ Ini berarti $\mathrm{H}_{0}$ ditolak, karena nilai dibawah

2. Jenis Kelamin

Analisis keragaman Jenis kelamin menjadi 2 kriteria yaitu Perempuan dan Laki - laki. Terdapat dua hipotesis umum yang diajukan $\mathrm{H}_{0} \quad$ : Tidak ada perbedaan jenis kelamin pelanggan yang mempengaruhi secara signifikan kepuasan pelanggan terhadap loyalitas pelanggan Duta Business School (DBS)

Berdasarkan hasil output keragaman lokasi tempat tinggal pelanggan pada model fit summary bagian Structural Weights, terlihat bahwa nilai probability yaitu 0 yang berarti bahwa nilai $p<0,05$. Hal ini menunjukkan

a) Kriteria Perempuan $(P)$

\begin{tabular}{|c|c|}
\hline $\mathrm{H}_{0}$ & $\begin{array}{l}\text { Tidak ada pengaruh secara } \\
\text { signifikan kepuasan pelanggan } \\
\text { terhadap loyalitas pelanggan oleh } \\
\text { pelanggan yang mempunyai jenis } \\
\text { kelamin } P \text {. }\end{array}$ \\
\hline $\mathrm{H}_{1}$ & $\begin{array}{l}\text { Ada pengaruh secara sign } \\
\text { kepuasan pelanggan terl }\end{array}$ \\
\hline
\end{tabular}

batas minimum yaitu 0,05 . Oleh karena itu dapat disimpulkan bahwa kepuasan pelanggan mempengaruhi secara signifikan loyalitas pelanggan oleh pelanggan yang mempunyai usia $>=25$ tahun

untuk analisis keragaman lokasi tempat tinggal pelanggan yaitu :

$\mathrm{H}_{1} \quad$ : Ada perbedaan jenis kelamin pelanggan yang mempengaruhi secara signifikan kepuasan pelanggan terhadap loyalitas pelanggan Duta Business School (DBS)

bahwa $\mathrm{H}_{0}$ ditolak yang berarti ada perbedaan jenis kelamin pelanggan yang mempengaruhi secara signifikan kepuasan pelanggan terhadap loyalitas pelanggan Duta Business School (DBS)

Hipotesis khusus yang diajukan pada penelitian ini untuk Perempuan adalah sebagai berikut :

loyalitas pelanggan oleh pelanggan yang mempunyai jenis kelamin $\mathrm{P}$

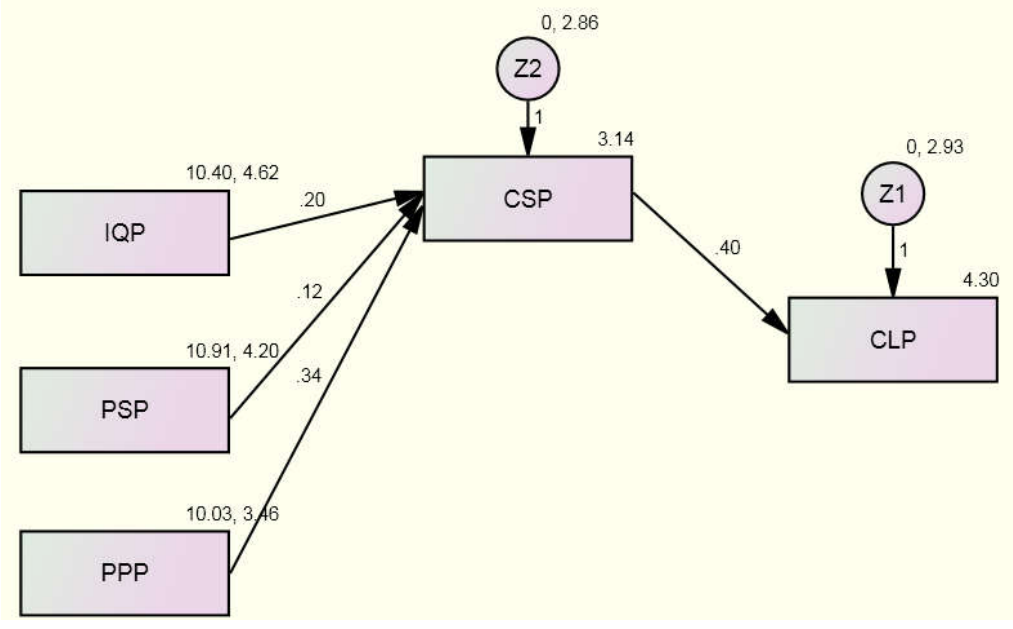

Gambar 9. Model Jalur P

Berdasarkan hasil output regression weights dengan kriteria perempuanbahwa hubungan antara Kepuasan Pelanggan dengan Loyalitas Pelanggan memiliki nilai $P=0,003$. Ini berarti 
$\mathrm{H}_{0}$ ditolak, karena nilai dibawah batas minimum yaitu 0,05 . Oleh karena itu dapat disimpulkan bahwa kepuasan pelanggan mempengaruhi

b.Kriteria Laki - laki (L).

$\mathrm{H}_{0}$ : Tidak ada pengaruh secara signifikan kepuasan pelanggan terhadap loyalitas pelanggan oleh pelanggan yang mempunyai jenis kelamin L. secara signifikan loyalitas pelanggan oleh pelanggan yang perempuan.

Hipotesis khusus yang diajukan pada penelitian ini untuk kriteria laki - laki adalah sebagai berikut :

$\mathrm{H}_{1}$ : Ada pengaruh secara signifikan kepuasan pelanggan terhadap loyalitas pelanggan oleh pelanggan yang mempunyai jenis kelamin $\mathrm{L}$

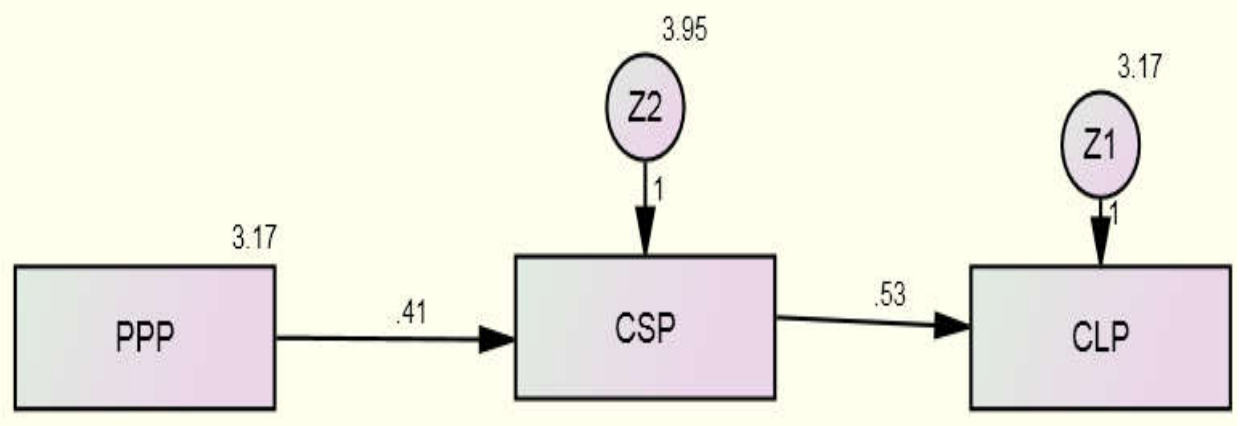

Gambar 10. Model Moderasi L

Berdasarkan hasil output regression weights dengan kriteria $\geq 3 \mathrm{~km}$ bahwa hubungan antara Kepuasan Pelanggan dengan Loyalitas Pelanggan memiliki nilai $\mathrm{P}={ }^{* * *}$. Ini berarti $\mathrm{H}_{0}$ ditolak, karena nilai dibawah batas minimum yaitu 0,05. Oleh karena itu dapat disimpulkan bahwa kepuasan pelanggan mempengaruhi secara signifikan loyalitas pelanggan oleh pelanggan yang laki - laki

\section{KESIMPULAN}

Model yang diajukan dalam penelitian ini adalah model Mustafa I.Eid (2011). Hasil pengujian menunjukkan bahwa model hanya fit terhadap sampel karena nilai probability< 0,05. Sehingga dapat disimpulkan bahwa model ini tidak dapat diekplorasi sebagai perilaku populasi dari obyek penelitian melainkan hanya mencerminkan perilaku dari sampel.

Berdasarkan hasil pengujian yang dilakukan, juga diperoleh kesimpulan bahwa tidak semua variabel dalam model yang diajukan berpengaruh terhadap kepuasan dan loyalitas pelanggan. Hasil analisa menunjukkan bahwa model tidak fit dengan populasi tetapi model hanya merepresentasikan sampel. Berdasarkan model yang diusulkan, Kualitas Antarmuka Web berdampak positif terhadap kepuasan pelanggan. Kualitas Informas, Privasi dan Keamanan sangat berkaitan dengan kepercayaan pelanggan dan kepuasan pelanggan dan Loyalitas pelanggan sangat berkaitan dengan Kepuasan pelanggan namun tidak memiliki pengaruh yang signifikan terhadap Kepercayaan pelanggan.

Berdasarkan uji keragaman variabel moderasi, diperoleh kesimpulan bahwa variabel moderasi sangat mempengaruhi Kepuasan pelanggan terhadap Loyalitas pelanggan 


\section{DAFTAR PUSTAKA}

Ainin Sulaiman, \& Noor Ismawati Jaafar. (2003, July). E-Commerce Stimuli and Practices in Malaysia. Proceedings of Seventh Pasific Asia Conference on Information Systems. Australia

Aisyah, Siti. (2011). Kajian Model dan Persepsi Penerimaan/Penggunaan Student Information Services : Studi Kasus Perguruan Tinggi Raharja. Program Studi Magister IImu Komputer, Universitas Budi Luhur.

Andi (2005). Pengaruh Strategi Pemasaran terhadap Kinerja Pemasaran dan Kinerja Perusahaan dengan Lingkungan Persaingan sebagai Variabel Moderating, Semarang, Universitas Diponegoro.

Blanca Hernández- Julio Jiménez-Martínez, , $\mathrm{M}^{\mathrm{a}}$ José Martín-De Hoyos (2008). B2C ECommerce Acceptance: The Moderating Effect of Gender Communications of the I"BIMA, Zaragoza, Spain University of Zaragoza Volume 6, 2008.

Chen et al (2009). Are educational background and gender moderator variables for leadership, satisfaction and organizational commitment? 1Department of Management Information System, Yung-Ta Institute of Technology and Commerce, Lin-Luoh, Pingtung 90941, Taiwan.Listyarso,

Harsono, Djoko. (2011). Kajian Efektivitas ELearning : Studi Kasus STMIK Indonesia. Program Studi Magister Ilmu Komputer, Universitas Budi Luhur.

Hasyim, M. (2010). Analisis Pengaruh Ekspektasi Kinerja, Ekspektasi Usaha, dan Faktor Sosial Terhadap Penggunaan Sistem Informasi (Studi Kasus PT. Semen Bosowa Maros, Makassar, Universitas Hasanuddin

I,Eid, Mustafa (2011). Determinants of ECommerce Customer Satisfaction, Trust, and Loyalty in Saudi Arabia. Journal of Electronic Commerce Research, Vol 12, No. 1.

M. Byrne, Barbara (2010). Structural Equation Modeling With AMOS: Basic Concepts, Applications, and Programming, 2nd edition",(pp. 3-9).

Muzahid Akbar, Mohammad \& Parvez, Noorjahan (2009). Impact of Service Quality, Trust, and Customer Satisfaction on Customers
Loyalty. ABAC Journal Vol. 29, No. 1 (January-April, pp.24-38).

Santoso, Singgih (2011). Struktural Equation Model (SEM) Konsep dan Aplikasi dengan AMOS 18. Elex Media Komputindo.

Saputra, Suparno (2007). Kajian Teoritis Services Quality, Satisfaction, Trust,Reputation, Switching Cost dan Loyalty. Competitive Majalah Ilmiah enam Bulanan Politeknik Pos Indonesia Vol. 2, No. 2, Desember 2007.

T. Marchewka, Jack, Liu, Chang, \& Kostiwa, Kurt (2009). An Application of The UTAUT Model for Understanding Student Perceptions using Course Management Software. Communications of the IIMA.

Wijayanti, Ari. (2008). Strategi Meningkatkan Loyalitas melalui Kepuasan Pelanggan. Program Studi Magister Manajemen, Universitas Diponegoro.

Yuan Hu, Hsiu et al. (2011). A Study of Customer Satisfaction, customer loyalty, and quality attributes in Taiwan's Medical Service Industry. African Journal of Business Management Vol. 5(1), pp. 187-195, 4 January. 